\title{
Research
}

\section{Relationships Between Perceived Coastal Waterway Condition and Social Aspects of Quality of Life}

\author{
$\underline{\text { Melanie E. Cox }}^{1}, \underline{\text { Ron Johnstone }}^{1}$, and $\underline{\text { Jackie Robinson }}^{2}$
}

\begin{abstract}
Previous research has shown that the presence of natural areas is beneficial to human wellbeing. However, to date there have been few published studies of the effects that the condition of natural areas have on well-being. We hypothesize that coastal waterways that are perceived to be in better condition are visited more often by local residents, and as a result, residents will develop a stronger sense of place and stronger social relations with other residents, which will in turn lead to a higher quality of life. A survey was conducted to test this hypothesis in two coastal regions in Queensland, Australia. A weak relationship was found between perceived coastal quality and the number of recreational visits. In both study areas, frequency of visits to coastal waterways was significantly related to quality of life through an increased sense of place and social contacts. In the Douglas region, sense of place and social capital were closely related, and social capital was also related to quality of life. In both study areas, residents were most likely to visit waterways that were located in close proximity to their residence, suggesting that management of all waterways is essential for human well-being, and that benefits to humans will result from rehabilitating degraded waterways.
\end{abstract}

Key Words: quality of life; waterway condition; coastal zone management

\section{INTRODUCTION}

Improving quality of life is one of the main objectives of policy makers throughout the world. The World Health Organization (WHO 1999:3) defines quality of life as "an individual's perception of their position in life in the context of the culture and value systems in which they live and in relation to their goals, expectations, standards and concerns. It is a broad concept affected in a complex way by a person's physical health, psychological state, personal beliefs, social relationships and their relationship to salient features of their environment."

Many potential determinants of quality of life have been examined, including financial security, health, length of residence in an area, satisfaction with work, education, perceived empowerment, social opportunities, loneliness, community belonging, living with a partner, living in a less densely populated area, family relations, housing, religion, and self-esteem (Chipuer et al. 2003, Cramer et al. 2004, Michalos 2004, Tay et al. 2004). However, the importance of the natural environment in quality of life has been largely overlooked. Respondents in quality of life studies have listed environmental quality as one of high importance to their quality of life (Vlek et al. 1998). Maller et al. (2002) state that contact with nature can improve physical health through improving cardiovascular and immune function, reducing physical responses to stress, promoting relaxation, and reducing the negative impact of illness. Contact with natural areas may also provide spiritual inspiration, feelings of peacefulness and freedom, and promote social activity and interaction with friends and family.

There is a diverse literature linking the presence of natural areas with specific aspects of human wellbeing. This literature comes from several disciplinary backgrounds, including environmental psychology, recreational studies, medicine, social capital, and place research. However, there have been as yet no attempts to directly link human wellbeing with the "quality" of natural areas, and no attempts to assess the effects of the quality of natural areas on different aspects of well-being within the same study. Therefore, the aims of this study are to 
test a series of hypotheses that link the condition of natural areas with several aspects of human social well-being. A brief summary of the literature on which these hypotheses are based is given below. The specific environment chosen for this study is coastal waterways, including estuaries, beaches, bays, and reefs in Queensland, Australia. Approximately $87 \%$ of Queenslanders live within $50 \mathrm{~km}$ of the coast (Australian Bureau of Statistics 2002), and the coastal population is experiencing rapid increases (Department of Local Government and Planning 2002). The condition of the coastal environment is therefore potentially declining, at the same time as its importance to the community is growing.

The presence of natural, open space has been found to contribute to the likelihood of people undertaking recreation. It has been found that recreation, including exercise, is positively related to a natural setting (Neff et al. 2000), and satisfaction with facilities, including parks (MacDougall et al. 1997). Similarly, perception of environmental quality may affect the type of recreation undertaken. For example, a perception of good water quality is more likely to result in people swimming in waterways (Smith et al. 1995, Pendleton et al. 2001). Recreation provides many potential benefits, including benefits to physical and mental health, self-identity, skill development and learning, spirituality, social cohesion, and community satisfaction (Driver et al. 1991). Therefore, it is hypothesized that the perceived condition of coastal waterways will affect the amount of recreation undertaken.

In city neighborhoods, the presence of greenery has been found to lead to a greater use of common spaces and face to face social contact. Neighbors who had face to face contact were more likely to develop and maintain social ties and networks (Kuo et al. 1998, Kweon et al. 1998). Therefore, it is hypothesized that recreation at coastal waterways will lead to increased social interaction. Social interaction is an important component of social well-being, because it is through personal interaction that individuals develop trust and supportive networks (Lochner et al. 1999, Svendsen and Svendsen 2000).

Social capital refers to the norms of understanding, trust, reciprocity, and networks within a community that facilitate cooperative action (Lochner et al. 1999, Onyx and Bullen 2000). Aspects of social capital such as levels of interpersonal trust, norms of reciprocity, and group membership have been found to be significantly related to morbidity and mortality rates from all causes of death (Kawachi 1999, Lochner et al. 1999, Rosenfeld et al. 2001). It is hypothesized that trust and reciprocity will be affected by levels of social interaction and social networks.

Social networks have been found to contribute directly to physical and mental health. A literature review of 19 studies found that individuals with higher levels of social support had higher immune responses and lower blood pressure (Uchino et al. 1999). Mortality risk was found to be twice as high for the most isolated people compared with the people with the most social contacts over a nine year study (Berkman and Syme 1979). Therefore, health and quality of life are hypothesized to be affected by social networks.

Sense of place is also potentially related to natural areas. Although definitions of sense of place vary, most authors agree that it incorporates both physical and social elements, which probably interact. Stedman (2003) states that the social component of sense of place is important, as it is through experience that people imbue a place with meaning, but it is the physical aspects of the place that set limits on the type of experience that can be had in a place and, therefore, on the type of meaning that can be constructed. Jorgensen and Stedman (2001:233) define sense of place as "the meaning attached to a spatial setting by a person or group." Place attachment has previously been found to be related to the perceived quality of residential areas (Bonaiuto et al. 1999). Sense of place contributes to overall quality of life in that it contributes to individual and group, neighborhood, or cultural identity (Williams et al. 1992, Chipuer and Pretty 1999). For example, communities in Alaska that had stronger place attachment were found to be more cohesive and had a higher perceived quality of life (Brown et al. 2002). Although there has been little research on the effect of the quality of the natural environment on sense of place, Stedman (2003) found that characteristics of a lakeshore environment were related to the residents' use of the area and place attachment. Sense of place is hypothesized to be a significant determinant of quality of life.

A number of hypothesized links between the condition of natural areas and human well-being can 
Fig. 1. Hypothesized relationships between waterway condition and quality of life.

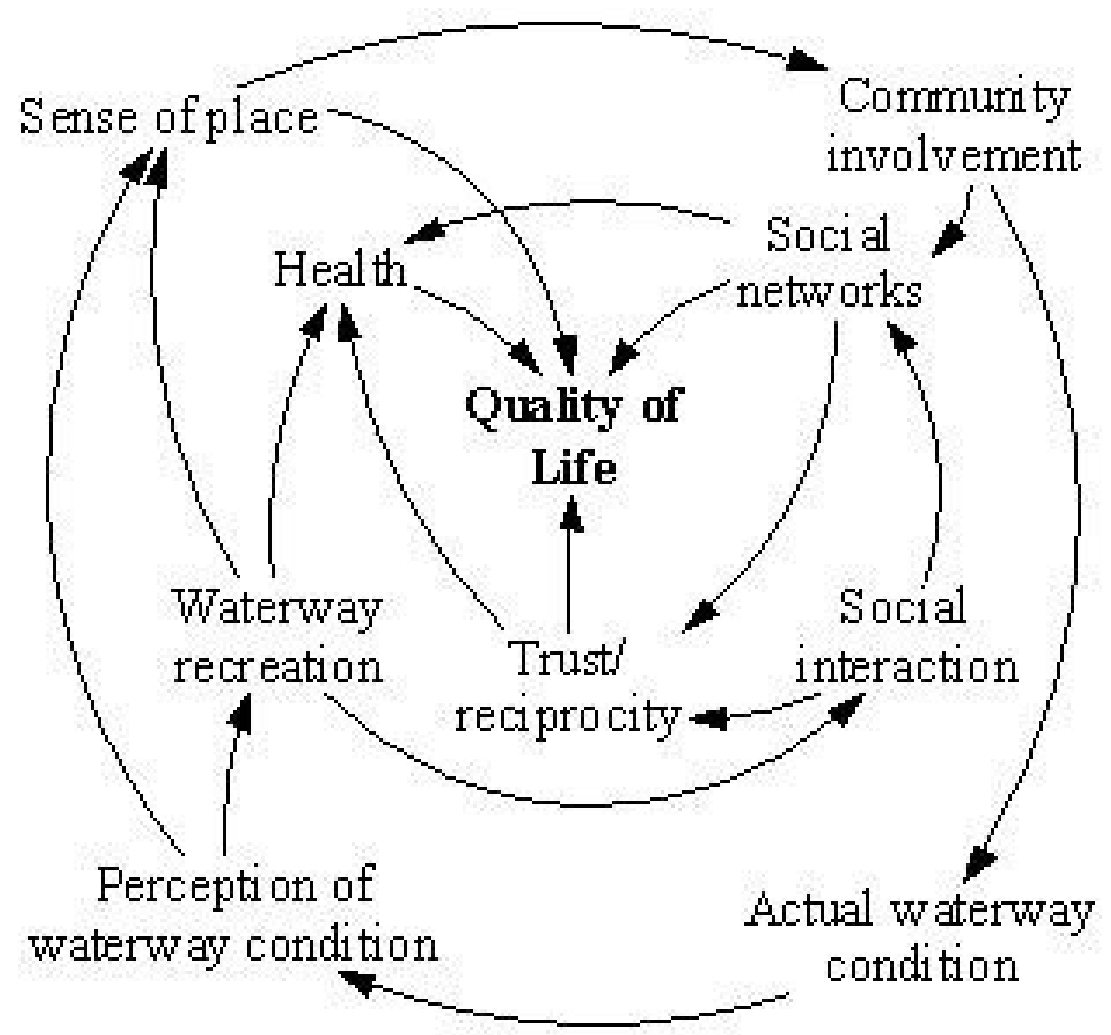

be drawn from the literature above. This paper presents and tests the hypotheses that residents are more likely to undertake recreation in areas of good perceived environmental quality, and that this recreation will lead to a higher level of physical place attachment and social interaction. Increased social interaction leads to wider social networks, increased feelings of trust and reciprocity, and a higher level of sociability. Place attachment is linked to sense of belonging, and commitment to place and place dependence. Higher commitment to place will lead to residents being more involved in community activities, including volunteering, and higher sense of belonging is an important component of overall quality of life. Wider networks increase feelings of trust and reciprocity and lead to a higher quality of life; trust and reciprocity lead to higher levels of sense of belonging and better quality of life. Quality of life is also related to health. These hypothesized links are shown in Fig. 1.

\section{METHODS}

\section{Study areas}

Two study areas located in Queensland, Australia, were chosen for the study (Fig. 2). The Pumicestone catchment lies approximately $60 \mathrm{~km}$ north of Brisbane. Major waterways in the catchment include Caboolture River, Deception Bay, and Pumicestone Passage. Several small creeks flow into Pumicestone Passage and there are surf beaches on Bribie Island and at Caloundra. Land use in the area is predominantly urban, with extensive areas of plantation forest adjoining Pumicestone Passage and some farming in the western areas.

The Douglas region lies approximately $60 \mathrm{~km}$ north of Cairns, in north Queensland. Major waterways in the region include the Mossman and Daintree Rivers, Saltwater Creek, Dickson Inlet, several creeks north of Daintree, and numerous beaches. 
Fig. 2. Maps of the study areas.

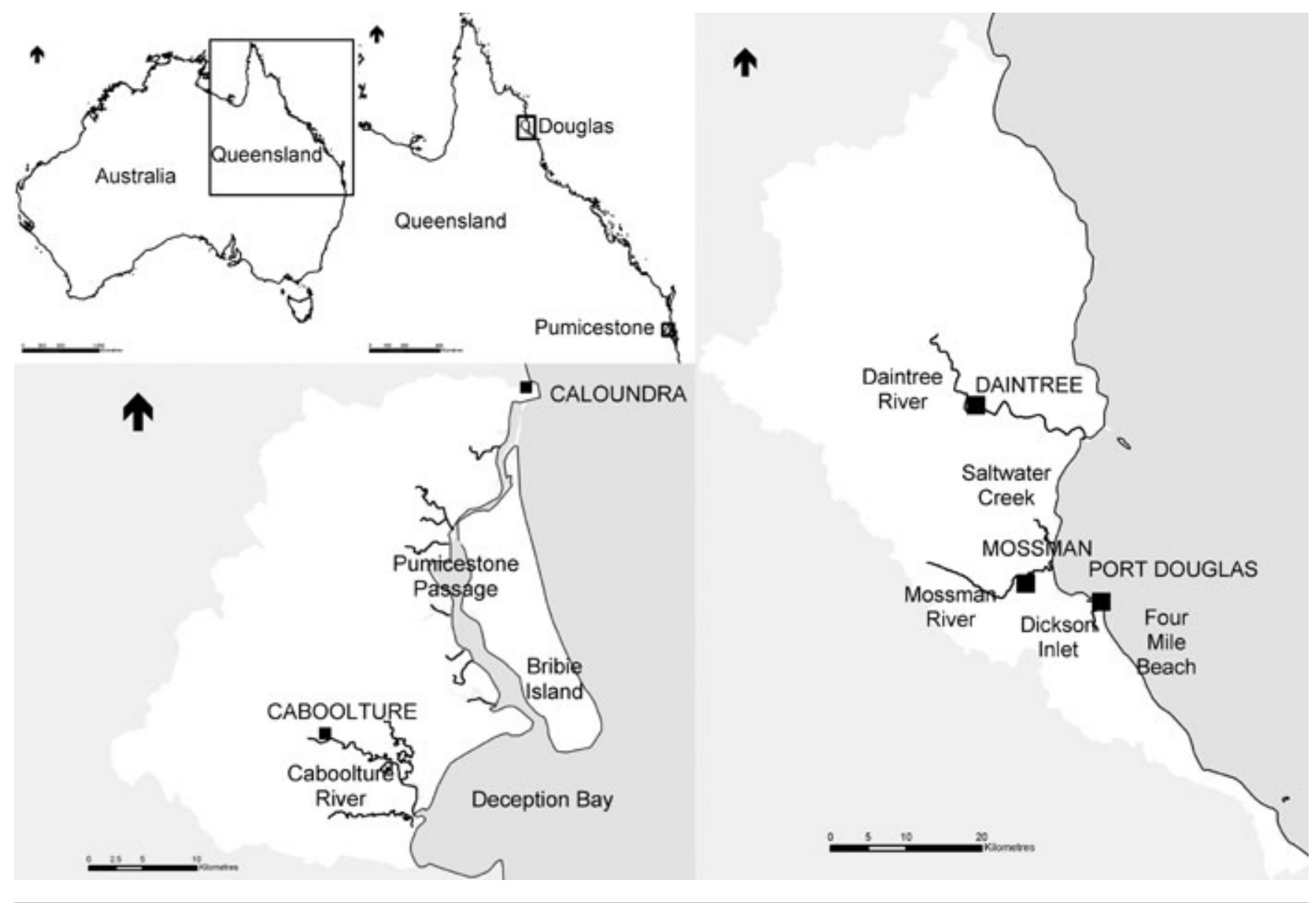

The Great Barrier Reef also lies just offshore. Land use in the area is predominantly natural vegetation, much of which is World Heritage listed rainforest. Much of the lowland areas have been cleared for cattle grazing, and the coastal plains for intensive agriculture. Basic social and economic characteristics of the population of both regions from the 2001 Australian Household Census are listed in Table 1.

\section{Survey}

A self-administered survey of residents in both study areas was conducted, consisting of two main sections. The first section included questions on sense of place, social interaction, physical and mental health, and quality of life. The second section covered perceptions of the condition of the major waterways in each study area, number of visits to each waterway, benefits gained from recreation, social contact during waterway visits, and general demographic information. Items related to the main variables are listed in Table 2 . With the exception of recreational visits, overall health and quality of life, all items were scored on a five-point Likert scale. Recreational visits were measured in actual number of visits over the previous $12 \mathrm{mo}$, and general health and quality of life were each scored on a six-point scale. Most items were identical in both surveys; however, a few items were regionally specific. Surveys were hand-delivered to randomly selected addresses in each study area. Surveying was conducted from April to June 2004, and contact was attempted by researchers at least twice at each address. The survey was designed to be self- 
Table 1. Social and economic characteristics of the study regions.

\begin{tabular}{|c|c|c|}
\hline Characteristic & Pumicestone & Douglas \\
\hline Total population (people) & 126942 & 9964 \\
\hline Total area $\left(\mathrm{km}^{2}\right)$ & 1070 & 2658 \\
\hline Population density (people $/ \mathrm{km}^{2}$ ) & 118.6 & 3.8 \\
\hline Indigenous population (\%) & 1.6 & 5.5 \\
\hline Estimated population growth $(2001-2026)(\%) \dagger$ & 2.6 & 2.0 \\
\hline Visitor nights 2002 & 270007 & 879187 \\
\hline Median age (total population) & 37 & 38 \\
\hline Education - did not finish high school (\%) & 46.6 & 32.7 \\
\hline Education - tertiary education $(\%)$ & 12.7 & 21.5 \\
\hline Unemployment rate $(\%)$ & 11.1 & 4.7 \\
\hline Mean household size & 2.7 & 2.5 \\
\hline$\%$ same address as $1 \mathrm{yr}$ previously & 79 & 75 \\
\hline$\%$ same address as $5 \mathrm{yr}$ previously & 50 & 49 \\
\hline
\end{tabular}

Unless otherwise stated, data are sourced from the Australian 2001 Household Census (Australian Bureau of Statistics 2002). $\dagger$ (Department of Local Government and Planning 2003) 
completed, and a reply-paid envelope was provided for respondents to post back the surveys.

\section{Analysis methods}

Responses with more than $20 \%$ of the answers missing were removed from the sample. For the remaining samples, any missing data points were replaced with the mean value for that variable (Kline 1998). Mean results for each of the major variables were compared between regions using a series of $t$ -tests.

Structural equation modeling (SEM) was used to analyze the relationships between waterway condition and well-being indicators. SEM is a term referring to a family of multivariate statistical techniques based on analysis of covariance matrices. The researcher specifies an expected covariance matrix based on theory, in which the matrix is made up of expected relationships among variables. The empirical covariance matrix for a set of data is then compared with the expected matrix; if the two are consistent, the theoretical model is supported. The significance of the relationships between particular pairs of variables, i.e., paths in the path analysis, is also tested individually; in a well-fitting model, all specified paths should be significant, and relationships between other pairs of variables should not be significant. Error covariances can also be specified in the model between pairs of variables, when the variables are expected to covary as a result of external factors when the variables are not causally related, but are expected to covary as a result of external factors. The main advantages of SEM are that it allows the indirect relationships between dependent variables to be estimated (c.f. multiple regression), and can explicitly represent both measured variables and their underlying concepts or latent variables. For example, income and educational achievement are commonly used measured variables that represent the latent construct "socioeconomic status." SEM is an a priori technique; the theoretical model must be specified in advance of data collection. However, SEM is rarely used as a purely confirmatory technique. Most commonly, the data may be slightly inconsistent with the hypothesized model, and the model is adjusted and reestimated. In this case, SEM may be used as a model generating technique, with the twin aims of identifying a model that has a sound theoretical basis and that is supported by data. This is the way in which SEM is used here; the hypothesized links are grounded in the existing literature, but have not been assessed previously in a single model. A good introduction to SEM is given by Kline (1998).

The SEM analysis was undertaken in two stages: testing the measurement and the structural models. It is possible to use SEM to perform a single analysis that estimates both the measurement and structural models at the same time. However, for a complicated analysis such as this, it is much easier to separate the two steps. The first stage, measurement reliability, involved testing the reliability of survey questions, i.e., measured variables, as measures of latent constructs. Measured variables and their respective latent variables are listed in Table 2. Measurement reliability was assessed using confirmatory factor analysis implemented in Lisrel 8.51 (Jöreskog and Sörbom 2001). Whenever possible, the measurement models for each latent variable were assessed separately. However, when a latent variable is represented by fewer than three measured variables, the model is saturated, i.e., there are no degrees of freedom, and cannot be assessed. In these cases, the measurement models for two latent variables were assessed simultaneously, e.g., health and quality of life.

The second stage of the analysis was to assess the structural model, i.e., to test the hypothesized relationships between the latent variables. The structural model was estimated using path analysis, which uses only measured variables. Therefore, a single measured variable was created for each of the latent variables by summing the scores, usually on a scale of 1 to 5 , for each of the related measured variables to create composite variables (Table 2), when the measurement model for that latent variable fit the data well. Other measured variables that were included in the model were the total number of visits to waterways in each region, the length of time, in years, that respondents had lived in the area, and the minimum distance respondents lived from all waterways. This distance was calculated by geocoding the address of each respondent against the digital cadastral database supplied by the relevant council using ArcView 8.1 (ESRI 1999), and calculating the distance between respondents' addresses and several locations on each waterway. The natural log of the average distance and length of residence was used in the analysis. Path analysis was then performed using Lisrel 8.51. The model 
Table 2. Survey items and corresponding latent variables.

\begin{tabular}{|c|c|}
\hline Latent variable & Survey item \\
\hline Recreational visits & Number of visits to each waterway in the last 12 mo \\
\hline Length of residence & Number of years lived in area \\
\hline Age & Age in years \\
\hline \multirow[t]{2}{*}{ Social place attachment } & I can recognise most of the people who live in this area. \\
\hline & When shopping in my local area, I am likely to run into people I know. \\
\hline \multirow{2}{*}{$\begin{array}{l}\text { Physical place } \\
\text { attachment }\end{array}$} & There are places in this area that are special to me. \\
\hline & I enjoy visiting places in this area. \\
\hline \multirow[t]{2}{*}{ Place belonging } & I feel I belong in this area. \\
\hline & I would like to continue living in this area. \\
\hline \multirow[t]{2}{*}{ Place commitment } & I would like to contribute to making this area a better place to live. \\
\hline & If there was a problem in this area I would help to fix it. \\
\hline \multirow[t]{3}{*}{ Place dependence } & This area is my favorite place to be. \\
\hline & I really miss this area when I'm away for too long. $\dagger$ \\
\hline & This area means a lot to me. $\ddagger$ \\
\hline $\begin{array}{l}\text { Social interaction, } \\
\text { experience }\end{array}$ & Visiting a waterway for recreation allows me to catch up with other locals. \\
\hline
\end{tabular}

Social interaction, casual When visiting a waterway for recreation, how often do you run into people you know? contact

When visiting a waterway for recreation, how many people who you know, would you normally see?

Social networks

How often do you generally see or talk with friends or family?

How many close friends or family do you have? 
Community involvement How often do you attend meetings, e.g., a church, sporting, craft, or social club?

How often do you perform voluntary work, e.g. environmental, educational, civic, volunteer work?

Health and quality of life In general, how would you rate your overall health?

In general, how would you rate your quality of life?

Health limitations $\quad$ How much do physical problems limit your usual activities?

How much do personal or emotional problems limit your usual activities?

Trust

Most people can be trusted.

If I lost a purse or wallet, it would be returned with the money in it, if it was found.

Reciprocity

If I don't have something I need I can borrow it from a neighbor.

I lend things and do favors for my neighbors.

Perceived waterway

Considering everything, how would you rate the overall condition of the following waterways?

condition

How would you rate the waterways in terms of the quality of the water?

How would you rate the waterways in terms of the vegetation along the shores?

How would you rate the waterways in terms of the number and variety of animals?

How would you rate the waterways in terms of the chances of people getting sick? $\dagger$

$\dagger$ Pumicestone region only

$\ddagger$ Douglas region only

was analyzed separately for both study areas using Lisrel 8.51, then each model was reassessed with the nonsignificant paths removed.

The relationship between perceived waterway condition and the number of visits to waterways was then investigated in more detail. Perceived waterway condition, distance to the coast, health, age, education, and sex of the respondents were included as predictors of waterway visits in a linear regression model for each waterway. The regression modeling was done using S-Plus 6.1 (Insightful 2001), assuming a normal error distribution. All variables were initially included in the model for each waterway, and then the models were estimated with nonsignificant variables removed.

\section{RESULTS}

\section{Response rate and respondent characteristics}

In the Pumicestone region, contact was attempted at 1134 dwellings. Of these, surveys were accepted by $831(73 \%), 118(11 \%)$ could not be contacted, and $185(16 \%)$ declined to participate. In the Douglas region, contact was attempted at 1197 dwellings. Of these, $238(20 \%)$ could not be contacted, 69 declined $(6 \%)$, and surveys were accepted at 890 dwellings $(74 \%)$. A total of 415 
responses were received from the Pumicestone region, and 419 from Douglas. Response rates as a percentage of people contacted were $40.8 \%$ and $43.7 \%$, respectively, and as a percentage of the surveys accepted $49.9 \%$ and $47 \%$, respectively. Respondents were randomly selected to minimize potential selection bias. However, some response bias may have existed in those residents who were more interested in coastal issues, or those who undertook more coastal recreation may have been more likely to return the survey. This potential bias is not quantifiable, but is likely to be small given the relatively high return rates.

Respondents were similar to the general population in each area in terms of age, education, and sex. In the Pumicestone region, respondents were slightly older than the general population aged over 18 (51 yr compared with $48, t$ test, $p<0.05)$. Respondents were also more likely to be female, e.g., $60 \%$ of respondents, compared with $51 \%$ of the general population, were less likely to have left school in years 8 or 10 , and more likely to have a diploma or bachelor degree. In the Douglas region, the average age of respondents, 46, was the same as the average age of the general population over 18-yr old. Fifty percent of respondents were female, the same as the general population. Respondents were more likely to have a diploma, and less likely to have left school at years 8 or 10 .

Mean results for each of the main variables in each region are shown in Table 3. For all variables except community involvement and perceived waterway condition, mean results were significantly higher in the Douglas than in the Pumicestone region.

\section{Measurement models}

Results of measurement model fit are given in Table 4. A graphical representation of the measurement models is given in Appendix 1. Most of the measurement models fit very well. The measurement models were identical for both areas, with the exception of the model for perceived water quality, which required extra error covariances between the measured variables for overall waterway condition and water quality in the Douglas region, suggesting that water quality played a stronger role in determining overall perceived waterway condition in this region.

\section{Path analysis}

The path analysis was conducted separately for the two study areas. The parameter estimates and $t$ values for each path are shown in Table 5, and the error covariances between related variables in Table 6. Path analysis model fit can be assessed using a number of measures, several of which are used here. A model is generally regarded as fitting well when the $\chi^{2}$ value is less than twice the degrees of freedom, the root mean square error of approximation (RMSEA) is less than 0.05, and the adjusted goodness of fit index (AGFI) is greater than 0.9 , ideally greater than 0.95 (Kline 1998). Overall model fit for the hypothesized model for both regions was good (Pumicestone $\chi^{2}=117.61$, $\mathrm{df}=$ $72, P<0.01$, RMSEA $=0.047$, AGFI $=0.9$; Douglas $\chi^{2}=130.1, \mathrm{df}=72, p<0.01$, RMSEA $=$ 0.047 , AGFI $=0.92$ ). Model fit improved slightly for both regions when nonsignificant paths were removed (Pumicestone $\chi^{2}=152.56, \mathrm{df}=93, p<0.01$, RMSEA $=0.048$, AGFI $=0.9$; Douglas $\chi^{2}=156.21$, $\mathrm{df}=84, P<0.01$, RMSEA $=0.049$, AGFI $=0.92$ ). The final path analysis diagrams are shown in Figs. 3 and 4 for Pumicestone and Douglas. Age, sex, and education were tested in the initial models as potential predictors of the number of visits, health, quality of life, and perceived water quality, but did not add to the explanatory power of the model.

The path analysis results are complicated; therefore, it helps to explain the relationships in words. In both study areas, there were two main paths between coastal environmental quality and human wellbeing. Increased recreation in coastal areas was related to stronger physical and social place attachment, which were in turn related to place belonging. Place belonging was a significant determinant of quality of life. Increased recreation also led to increased social interaction, which was positively related to social networks and was also a significant determinant of quality of life. Physical and social place attachment were also related to the other sense of place domains of place dependence and place commitment. Commitment to place was positively related to involvement in community activities, including volunteering. Social place attachment and networks were related to higher levels of reciprocal behavior. Larger networks also led to a greater sense of belonging and social sense of place. Increased length of residence contributed to social place attachment. Health and quality of life were also related to health limitations. 
Table 3. Mean result for each variable in each region and $P$ value for $t$-test of difference between the regions.

\begin{tabular}{|c|c|c|c|c|}
\hline Variable & Maximum & Pumicestone & Douglas & $P$ value \\
\hline Physical place attachment & 10 & 7.86 & 8.92 & 0.0000 \\
\hline Social place attachment & 10 & 6.80 & 8.11 & 0.0000 \\
\hline Place belonging & 10 & 8.10 & 8.96 & 0.0000 \\
\hline Place commitment & 10 & 8.01 & 8.47 & 0.0000 \\
\hline Place dependence & 10 & 7.09 & 8.61 & 0.0000 \\
\hline Community involvement & 10 & 4.61 & 4.35 & 0.1670 \\
\hline Social networks & 10 & 7.39 & 7.76 & 0.0015 \\
\hline Social interaction & 20 & 10.76 & 12.20 & 0.0000 \\
\hline Length of residence & - & 12.31 & 15.52 & 0.0021 \\
\hline Average waterway condition & 5 & 3.45 & 3.50 & 0.3191 \\
\hline Visits per waterway & 365 & 15.36 & 24.72 & 0.0000 \\
\hline Trust & 10 & 5.68 & 6.72 & 0.0000 \\
\hline Reciprocity & 10 & 7.43 & 8.13 & 0.0000 \\
\hline Health limitations & 10 & 8.28 & 8.90 & 0.0000 \\
\hline Health & 6 & 4.38 & 4.71 & 0.0000 \\
\hline Quality of life & 6 & 4.57 & 4.92 & 0.0000 \\
\hline
\end{tabular}


Table 4. Measurement model fit for Pumicestone and Douglas. RMSEA stands for the root mean square error of approximation and AGFI, the adjusted goodness of fit index.

\begin{tabular}{lcccccccc}
\hline \hline Latent variables & \multicolumn{3}{c}{ Pumicestone } & & \multicolumn{3}{c}{ Douglas } \\
& $\begin{array}{l}\text { Chi Squ- } \\
\text { are }\end{array}$ & df & RMSEA & AGFI & $\begin{array}{c}\text { Chi Squ- } \\
\text { are }\end{array}$ & df & RMSEA & AGFI \\
& 52.96 & 25 & 0.052 & 0.94 & 55.87 & 25 & 0.055 & 0.94 \\
\hline Sense of place & 3.04 & 1 & 0.074 & 0.96 & 0.33 & 1 & 0 & 1 \\
Social interaction & 0.01 & 1 & 0 & 1 & 1.64 & 1 & 0.04 & 0.98 \\
$\begin{array}{l}\text { Social networks, community } \\
\text { involvement }\end{array}$ & 1.01 & 1 & 0.005 & 0.99 & 0.11 & 1 & 0 & 1 \\
$\begin{array}{l}\text { Trust, reciprocity } \\
\text { Perceived waterway condition }\end{array}$ & 398.21 & 215 & 0.055 & 0.84 & 414.54 & 219 & 0.049 & 0.87
\end{tabular}

$\dagger$ The measured variables that correspond to each latent variable are given in Table 2. Relationships are described in Appendix 3.

In the Pumicestone region, place dependence and physical place attachment were also affected by social interaction. Respondents who had lived in the area longer had larger networks, and respondents with larger networks had higher levels of trust. Respondents who lived closer to waterways had higher levels of social interaction. People who visited waterways more often also had higher levels of community involvement. Increased sense of belonging was related to better health, and people with fewer health limitations were more likely to visit waterways.

In the Douglas region, belonging and dependence aspects of sense of place were related to higher levels of trust and reciprocity; commitment to place was also affected by levels of reciprocity. Respondents who had lived in the area longer had higher levels of physical and social place attachment, place dependence, and belonging, but commitment to place was not related to length of residence. Higher levels of trust led to better reported health. Trust was affected by social place attachment; reciprocity was affected by levels of social interaction and social place attachment; reciprocity was also related to place commitment and networks to place attachment. Greater community involvement also increased network size and improved health. Trust, community involvement, and visits to waterways were also related to quality of life.

\section{Perceived waterway condition and number of waterway visits}

Results of the linear modeling for the number of waterway visits are given in Tables 7 and 8 for the Pumicestone and Douglas regions, respectively. All models for both study areas were significant at $P$ $<0.0001$. In the Pumicestone region, $R^{2}$ values ranged from 0.19 for visits to Caboolture River to 
Table 5. Parameter estimates for the full path model for each region.

\begin{tabular}{|c|c|c|c|c|c|c|c|}
\hline \multirow[t]{2}{*}{ Effect variable } & \multirow[t]{2}{*}{ Cause variables } & \multicolumn{3}{|c|}{ Pumicestone } & \multicolumn{3}{|c|}{ Douglas } \\
\hline & & $\begin{array}{l}\text { Standardized } \\
\text { parameter est- } \\
\text { imate }\end{array}$ & $t$ value $\dagger$ & $R^{2}$ & $\begin{array}{l}\text { Standardized } \\
\text { parameter est- } \\
\text { imate }\end{array}$ & $t$ value $\dagger$ & $R^{2}$ \\
\hline \multirow[t]{3}{*}{ Waterway visits } & Health limitations & 0.10 & 2.55 & 0.18 & 0.07 & 1.62 & 0.05 \\
\hline & $\begin{array}{l}\text { Distance from } \\
\text { waterways }\end{array}$ & -0.47 & -7.21 & & -0.18 & -3.77 & \\
\hline & Perceived water quality & 0.03 & 1.29 & & -0.01 & -0.31 & \\
\hline \multirow{4}{*}{$\begin{array}{l}\text { Physical place } \\
\text { attachment }\end{array}$} & Interaction & 0.13 & 4.37 & 0.19 & 0.002 & 0.09 & 0.13 \\
\hline & Networks & 0.07 & 1.03 & & 0.21 & 4.78 & \\
\hline & Waterway visits & 0.25 & 3.55 & & 0.18 & 3.51 & \\
\hline & Length of residence & 0.11 & 1.47 & & 0.17 & 2.86 & \\
\hline \multirow[t]{3}{*}{ Social place attachment } & Interaction & 0.23 & 7.50 & 0.27 & 0.12 & 4.69 & 0.17 \\
\hline & Networks & 0.22 & 3.14 & & 0.18 & 3.51 & \\
\hline & Length of residence & 0.25 & 3.04 & & 0.26 & 3.80 & \\
\hline \multirow[t]{6}{*}{ Place belonging } & Networks & 0.12 & 2.44 & 0.37 & 0.11 & 2.23 & 0.35 \\
\hline & Physical place & 0.45 & 8.23 & & 0.55 & 7.96 & \\
\hline & Social place & 0.21 & 4.32 & & 0.15 & 2.54 & \\
\hline & Trust & 0.07 & 1.45 & & 0.18 & 3.06 & \\
\hline & Reciprocity & -0.02 & -0.43 & & 0.21 & 3.30 & \\
\hline & Length of residence & 0.11 & 1.57 & & 0.21 & 2.72 & \\
\hline
\end{tabular}




\begin{tabular}{|c|c|c|c|c|c|c|c|}
\hline \multirow[t]{4}{*}{ Place commitment } & Physical place & 0.33 & 7.52 & 0.26 & 0.34 & 6.57 & 0.22 \\
\hline & Social place & 0.13 & 3.26 & & 0.17 & 3.76 & \\
\hline & Reciprocity & 0.05 & 1.40 & & 0.12 & 2.64 & \\
\hline & Length of residence & -0.05 & -0.85 & & -0.04 & -0.62 & \\
\hline \multirow[t]{6}{*}{ Place dependence } & Interaction & 0.09 & 3.10 & 0.50 & 0.04 & 1.45 & 0.39 \\
\hline & Physical place & 0.72 & 11.93 & & 0.79 & 9.62 & \\
\hline & Social place & 0.22 & 3.91 & & 0.23 & 3.19 & \\
\hline & Trust & 0.1 & 1.85 & & 0.22 & 3.11 & \\
\hline & Reciprocity & -0.07 & -1.31 & & 0.16 & 2.10 & \\
\hline & Length of residence & 0.03 & 0.43 & & 0.36 & 3.82 & \\
\hline \multirow[t]{3}{*}{ Social interaction } & Waterway visits & 0.86 & 6.06 & 0.20 & 0.47 & 3.62 & 0.07 \\
\hline & $\begin{array}{l}\text { Distance from } \\
\text { waterways }\end{array}$ & -0.47 & -2.77 & & -0.32 & -2.56 & \\
\hline & Length of residence & 0.41 & 2.87 & & 0.26 & 1.83 & \\
\hline \multirow[t]{3}{*}{ Networks } & Interaction & 0.11 & 4.51 & 0.12 & 0.16 & 6.64 & 0.16 \\
\hline & Length of residence & 0.20 & 2.92 & & 0.11 & 1.67 & \\
\hline & Community involvement & 0.05 & 1.87 & & 0.13 & 4.03 & \\
\hline \multirow[t]{2}{*}{ Community involvement } & Place commitment & 0.30 & 2.38 & 0.05 & 0.31 & 3.50 & 0.05 \\
\hline & Waterway visits & 0.32 & 2.54 & & 0.07 & 0.70 & \\
\hline \multirow[t]{2}{*}{ Trust } & Networks & 0.22 & 3.05 & 0.07 & 0.04 & 0.75 & 0.06 \\
\hline & Social interaction & 0.06 & 1.74 & & 0.02 & 0.89 & \\
\hline
\end{tabular}




\begin{tabular}{|c|c|c|c|c|c|c|c|}
\hline & Social place & 0.02 & 0.34 & & 0.19 & 3.66 & \\
\hline \multirow[t]{3}{*}{ Reciprocity } & Networks & 0.21 & 2.77 & 0.10 & 0.18 & 3.61 & 0.17 \\
\hline & Interaction & 0.06 & 1.61 & & 0.08 & 3.10 & \\
\hline & Social place & 0.15 & 2.35 & & 0.20 & 4.17 & \\
\hline \multirow[t]{6}{*}{ Health } & Place belonging & 0.09 & 2.87 & 0.39 & 0.02 & 0.94 & 0.35 \\
\hline & Networks & 0.03 & 0.82 & & 0.04 & 1.42 & \\
\hline & Trust & 0.02 & 0.68 & & 0.05 & 1.80 & \\
\hline & Health limitations & 0.37 & 12.88 & & 0.37 & 12.71 & \\
\hline & Community involvement & -0.02 & -0.98 & & 0.07 & 3.64 & \\
\hline & Waterway visits & -0.06 & -1.36 & & 0.06 & 1.61 & \\
\hline \multirow[t]{6}{*}{ Quality of life } & Place belonging & 0.16 & 5.34 & 0.34 & 0.10 & 4.84 & 0.33 \\
\hline & Networks & 0.15 & 4.27 & & 0.11 & 4.05 & \\
\hline & Trust & 0.05 & 1.68 & & 0.08 & 2.85 & \\
\hline & Health limitations & 0.23 & 8.54 & & 0.23 & 8.36 & \\
\hline & Community involvement & -0.004 & -0.24 & & 0.04 & 2.11 & \\
\hline & Waterway visits & -0.02 & -0.43 & & 0.08 & 2.56 & \\
\hline
\end{tabular}

$\dagger$ a $t$-value of greater than 1.96 is significant at $p<0.05$.

0.45 for visits to Pumicestone Passage. For all waterways, the distance respondents lived from each waterway was a significant predictor of the visits to that waterway; respondents who lived closer to the waterway visited more often. Visits to most waterways were positively related to visits to other waterways. Age was also a significant predictor of visits to some waterways; older residents were significantly more likely to visit Pumicestone Passage, but less likely to visit Bribie and Caloundra beaches.

Some aspects of waterway condition were significant in predicting the number of visits to most 
Table 6. Error covariances between related variables for the full path model in each region.

\begin{tabular}{|c|c|c|c|c|c|}
\hline \multicolumn{2}{|c|}{ Error covariances } & \multicolumn{2}{|c|}{ Pumicestone } & \multicolumn{2}{|c|}{ Douglas } \\
\hline Variable 1 & Variable 2 & Covariance & $t$ value $\dagger$ & Covariance & $t$ value $\dagger$ \\
\hline Social place & Physical place & 0.35 & 2.82 & 0.35 & 3.85 \\
\hline Place commitment & Place belonging & 0.47 & 5.46 & 0.53 & 5.25 \\
\hline Place dependence & Place belonging & 1.02 & 8.13 & 1.77 & 9.74 \\
\hline Place dependence & Place commitment & 0.38 & 4.1 & 0.61 & 5.02 \\
\hline Trust & Reciprocity & 0.68 & 4.28 & 0.53 & 5.24 \\
\hline Quality of life & Health & 0.29 & 7.15 & 0.24 & 7.16 \\
\hline
\end{tabular}

$\dagger \mathrm{A} t$ value $>1.96$ is significant at $p<0.05$.

waterways. Pumicestone Passage was the only waterway in which perceived condition did not affect the number of visits made. Visits to Caloundra beaches increased with a perceived lower risk to human health, and visits to Deception Bay were related to perceived water quality. The number of visits to Bribie beaches was also positively related to perceived water quality, but negatively related to overall condition. On the other hand, visits to Caboolture River were negatively related to water quality, but positively related to perceived biotic diversity in the waterway.

In the Douglas region, $R^{2}$ values ranged from 0.26 for visits to the northern beaches, to 0.53 for visits to Dickson Inlet and Four Mile Beach. Visits to all waterways except the reefs were higher for those residents who lived closer to the waterway. Again, visits to most waterways were related to the number of visits to other waterways. In terms of respondent characteristics, older people were less likely to visit the reef, males were more likely to visit the reef and Mossman River, and frequent visitors to Four Mile
Beach were more likely to have a higher level of education, and report fewer physical health limitations, but a greater level of mental or emotional limitations. In terms of perceived waterway condition, perceived overall condition was negatively related to visits to Dickson Inlet, water quality was positively related to visits to Saltwater Creek, perceived quality of vegetation was negatively related to visits to the Daintree River, and faunal diversity was positively related to visits to Four Mile Beach.

\section{DISCUSSION}

\section{Relationships between waterway condition and quality of life determinants}

The hypothesis that residents would visit waterways perceived to be in good condition more frequently than those perceived to be in poor condition was weakly supported by the regression analysis. For most waterways, one or more specific aspects of 
Fig. 3. Significant paths between perceived waterway condition and quality of life in the Pumicestone region. Paths in bold are common to both study areas.

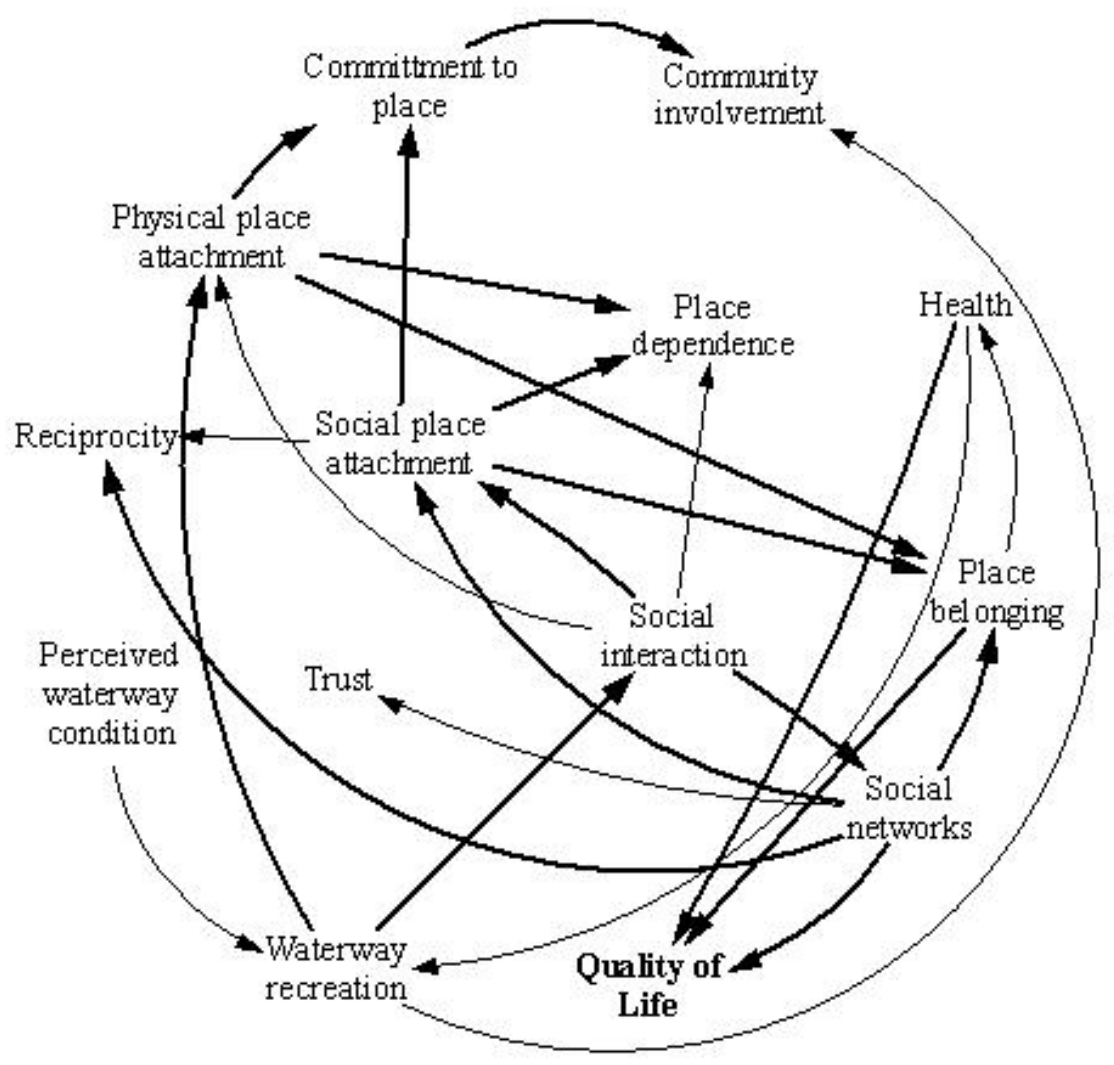

waterway condition were significantly related to the number of visits. However, the aspect of waterway condition that was related to visitation frequency varied between waterways, suggesting that the importance of waterway condition in terms of the frequency of visitation may vary depending on the purpose of the visit. The hypothesis was not supported by the path analysis, because using the total number of visits and the average rating for waterway condition masked the relationships between different aspects of waterway condition and visitation rates for different waterways.
The number of visits made to waterways was positively related to physical place attachment in the path analysis. This is consistent with theory, which states that sense of place develops through interaction with spaces, and that the place takes on meaning through the process of interaction (Pretty et al. 2003, Stedman 2003). However, place attachment was not related to perceived waterway condition. Stedman (2003) found, in a study of lakeshore communities in the United States, that the relationship between perceived lake quality and place attachment depended upon the use of the lake. When the lake was viewed as a social place, there 
Fig. 4. Significant paths between perceived waterway condition and quality of life in the Douglas region. Paths in bold are common to both study areas.

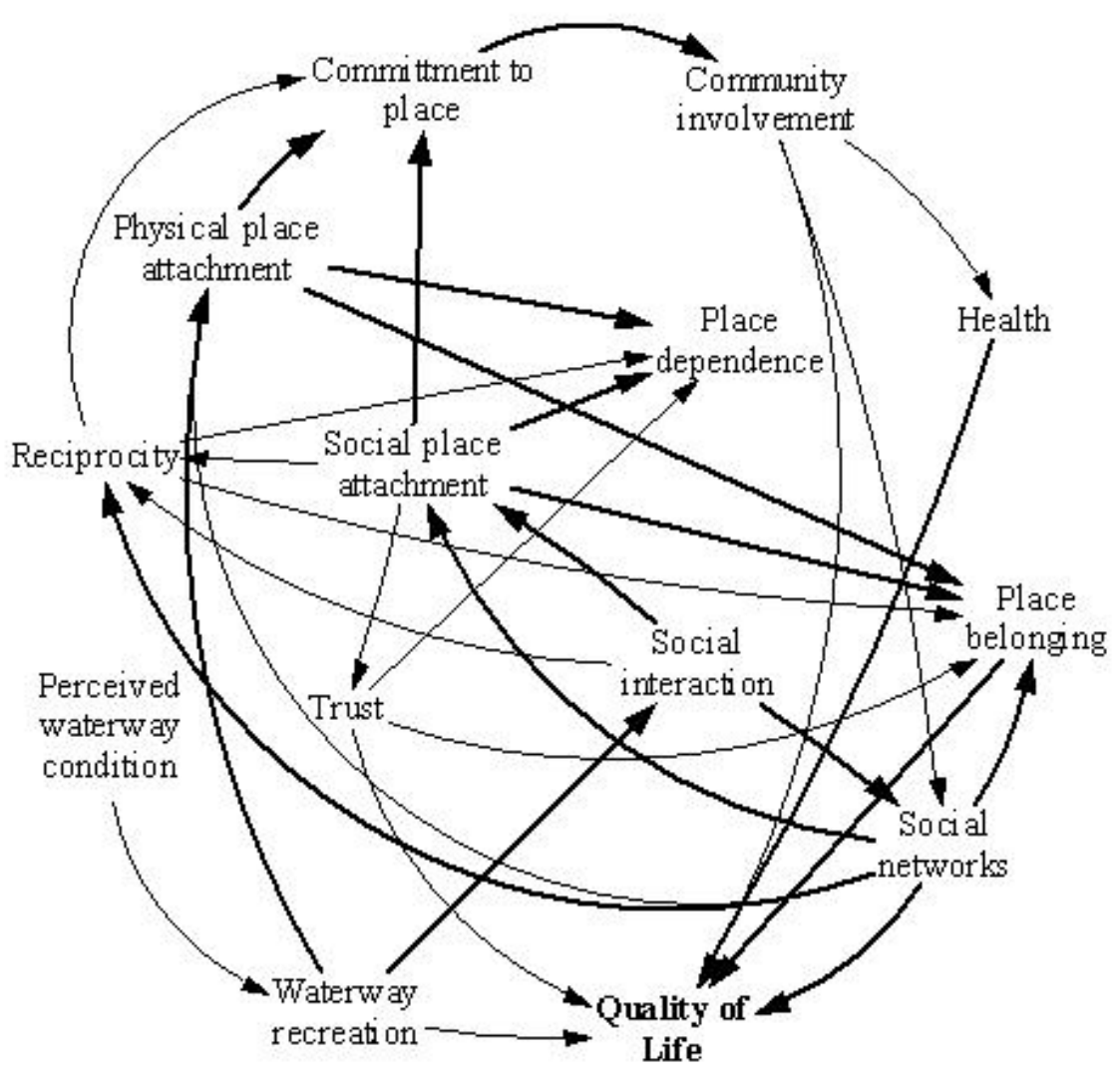

was a negative relationship between perceived water quality and attachment; when the lake was viewed as a place of escape, a positive relationship was found. This suggests that different aspects of waterway condition may be relevant for different uses of the waterway.

\section{Determinants of quality of life}

The significant relationships in the path analysis indicated that social networks contributed positively to quality of life but not physical and mental health in both study areas. This was surprising, because many previous studies have found strong links between network size and physical or mental health (Berkman and Syme 1979, Romans et al. 1992, Cohen et al. 1997, Achat et al. 1998). Trust was not related to self-assessed health in either region, although it was related to quality of life in the Douglas region. This also contrasts with previous results, which have found levels of trust to be significantly related to morbidity and mortality rates at a regional level (Kennedy and Kawachi 1998, Kawachi 1999). It is possible that the indicator of health used in this study, i.e., self- 
Table 7. Regression coefficients $(r)$ and $\mathrm{p}$ values for recreational visits to waterways, Pumicestone region

\begin{tabular}{|c|c|c|c|c|c|c|c|c|c|c|}
\hline \multirow[t]{2}{*}{ Independent variables } & \multicolumn{2}{|c|}{ Pumicestone } & \multicolumn{2}{|c|}{ Bribie beaches } & \multicolumn{2}{|c|}{ Caloundra beaches } & \multicolumn{2}{|c|}{ Caboolture River } & \multicolumn{2}{|c|}{ Deception Bay } \\
\hline & $r$ & $P \dagger$ & $r$ & $P$ & $r$ & $P$ & $r$ & $P$ & $r$ & $P$ \\
\hline Distance from waterway & -1.200 & 0.000 & -0.770 & 0.000 & -0.810 & 0.000 & -0.640 & 0.000 & -0.990 & 0.000 \\
\hline $\begin{array}{l}\text { Minimum distance from } \\
\text { coast }\end{array}$ & & & & & & & & & -0.140 & 0.060 \\
\hline Visits to Pumicestone & & & 0.170 & 0.001 & & & 0.210 & 0.000 & & \\
\hline Visits to Bribie & 0.300 & 0.000 & & & 0.170 & 0.001 & & & & \\
\hline Visits to Caloundra & 0.430 & 0.000 & 0.150 & 0.007 & & & & & 0.140 & 0.056 \\
\hline Visits to Caboolture & 0.150 & 0.008 & 0.130 & 0.010 & & & & & 0.290 & 0.000 \\
\hline Visits to Deception Bay & & & & & & & 0.170 & 0.001 & & \\
\hline $\begin{array}{l}\text { Overall waterway } \\
\text { condition }\end{array}$ & & & -0.170 & 0.033 & & & & & & \\
\hline Water quality & & & 0.090 & 0.016 & & & -0.110 & 0.030 & 0.080 & 0.000 \\
\hline \multicolumn{11}{|l|}{ Vegetation } \\
\hline Diversity & & & & & & & 0.120 & 0.011 & & \\
\hline Human health & & & & & 0.080 & 0.004 & & & & \\
\hline \multicolumn{11}{|l|}{ Mental health limitations } \\
\hline \multicolumn{11}{|l|}{ Physical health limitations } \\
\hline Age & 0.020 & 0.000 & -0.010 & 0.035 & -0.020 & 0.000 & & & & \\
\hline
\end{tabular}

Education 


\begin{tabular}{|c|c|c|c|c|c|}
\hline$F(\mathrm{df})$ & $61.1(5,368)$ & $31.6(7,307)$ & $52.0(4,284)$ & $12.36(5,263)$ & $18.6(5,271)$ \\
\hline$R^{2}$ & 0.45 & 0.42 & 0.42 & 0.19 & 0.26 \\
\hline
\end{tabular}

$\dagger$ Non-significant results are not displayed

assessed health, was not specific enough to exhibit links with trust or networks, although self-assessed health has been found to be a good predictor of future morbidity and mortality (Idler and Benyamini 1997).

Communities in Alaska with stronger place attachment have previously been found to be more cohesive and have a higher quality of life (Brown et al. 2002). The relationship between place, social cohesion, and quality of life was supported by this study, which found that place belonging was related to both social and physical aspects of sense of place, but the relationship with the physical aspect was stronger. Although community and self-identity are considered important components of quality of life, there has been little recognition that these may be related to place attachment. This provides strong support for the hypothesis that the condition of the local environment is important to human wellbeing.

The conclusions drawn here are necessarily limited by the data collection and analysis methods. A selfadministered survey technique was chosen as a large sample size was required, and there was limited time available to administer the survey. Selfadministered surveys are the most common form of surveys used, because they are usually simpler, cheaper, and quicker to administer (Dillman 1991). One potential limitation of self-administered surveys is that of nonresponse bias, which occurs when respondents who do not return their surveys differ in some way from the general population. In this case, this was minimized by using face to face recruitment of respondents to improve response rates. In terms of item response bias, selfadministered surveys are generally considered to reduce the incidence of respondents recording socially desirable answers compared with phone or personal interviews, and may be less subject to order effects, which promote the tendency of respondents to choose either the first or last option presented to them (Dillman 1991). Self-administered surveys may be subject to a context effect, when respondents' responses may be influenced by preceding or following questions. However, this may actually reduce error in responses, as respondents are able to check their answers for consistency.

SEM and path analysis were chosen for the analysis because they permit both direct and indirect relationships between variables to be measured, and can be used to test the measurement models for latent variables. However, there are a few limitations with these techniques. Only linear relationships can be assessed, and two-way interactions between variables cannot be assessed. For example, although the link between coastal condition and human well-being is modeled here as a one-way path, in reality it is likely that there is positive feedback between the two. As people become more involved in their local community, particularly with volunteer work, they are more likely to contribute to actions or lobbying to improve the local environment. Several authors have found that in areas with higher levels of trust, residents are more likely to get involved in local action and have more influence on local governments (Kawachi 1999, Sobels et al. 2001), and that people with stronger regional identity provided more support for environmental legislation (Carrus et al. 2005). However, these feedback loops were not investigated here, because SEM is not designed to analyze these types of feedbacks. The other major limitation to the study is that all relationships are correlations, and the direction of causality between 
Table 8. Regression coefficients $(r)$ and $P$ values for recreational visits to waterways, Douglas region.

\begin{tabular}{|c|c|c|c|c|c|c|c|c|c|c|c|c|c|c|}
\hline \multirow[t]{2}{*}{$\begin{array}{l}\text { Independent } \\
\text { variables }\end{array}$} & \multicolumn{2}{|c|}{$\begin{array}{l}\text { Four Mile } \\
\text { Beach }\end{array}$} & \multicolumn{2}{|c|}{ Dickson Inlet } & \multicolumn{2}{|c|}{$\begin{array}{l}\text { Mossman Ri- } \\
\text { ver }\end{array}$} & \multicolumn{2}{|c|}{$\begin{array}{l}\text { Saltwater C- } \\
\text { reek }\end{array}$} & \multicolumn{2}{|c|}{ Daintree River } & \multicolumn{2}{|c|}{$\begin{array}{l}\text { Northern Be- } \\
\text { aches }\end{array}$} & \multicolumn{2}{|c|}{ Reef } \\
\hline & $r$ & $P \dagger$ & $r$ & $P$ & $r$ & $P$ & $r$ & $P$ & $r$ & $P$ & $r$ & $P$ & $r$ & $P$ \\
\hline $\begin{array}{l}\text { Distance fr- } \\
\text { om waterway }\end{array}$ & -0.560 & 0.000 & -0.230 & 0.001 & -0.450 & 0.000 & -0.530 & 0.000 & -1.000 & 0.000 & -0.310 & 0.000 & & \\
\hline $\begin{array}{l}\text { Minimum } \\
\text { distance from } \\
\text { waterway }\end{array}$ & & & & & & & & & 0.160 & 0.014 & -0.280 & 0.001 & & \\
\hline $\begin{array}{l}\text { Visits to } \\
\text { Four Mile } \\
\text { Beach }\end{array}$ & & & 0.510 & 0.000 & & & & & 0.117 & 0.004 & & & & \\
\hline $\begin{array}{l}\text { Visits to } \\
\text { Dickson Inlet }\end{array}$ & 0.430 & 0.000 & & & & & 0.210 & 0.000 & & & & & 0.320 & 0.000 \\
\hline $\begin{array}{l}\text { Visits to } \\
\text { Mossman } \\
\text { River }\end{array}$ & & & & & & & 0.440 & 0.000 & 0.370 & 0.000 & 0.115 & 0.077 & & \\
\hline $\begin{array}{l}\text { Visits to } \\
\text { Saltwater } \\
\text { Creek }\end{array}$ & -0.080 & 0.090 & 0.140 & 0.004 & 0.400 & 0.000 & & & & & 0.170 & 0.005 & & \\
\hline $\begin{array}{l}\text { Visits to } \\
\text { Daintree R- } \\
\text { iver }\end{array}$ & 0.130 & 0.017 & & & 0.240 & 0.000 & 0.180 & 0.000 & & & 0.270 & 0.000 & & \\
\hline $\begin{array}{l}\text { Visits to } \\
\text { Northern } \\
\text { beaches }\end{array}$ & & & & & 0.100 & 0.008 & & & & & & & 0.130 & 0.001 \\
\hline $\begin{array}{l}\text { Visits to } \\
\text { reef }\end{array}$ & & & 0.350 & 0.000 & & & & & & & & & & \\
\hline $\begin{array}{l}\text { Overall wa- } \\
\text { terway con- } \\
\text { dition }\end{array}$ & & & -0.170 & 0.030 & & & -0.170 & 0.094 & & & & & 0.110 & 0.070 \\
\hline Water quality & -0.090 & 0.055 & & & & & 0.110 & 0.017 & & & 0.080 & 0.060 & & \\
\hline
\end{tabular}




\begin{tabular}{|c|c|c|c|c|c|c|c|c|}
\hline Vegetation & & $0.060 \quad 0.080$ & & & $-0.080 \quad 0.006$ & & & \\
\hline Diversity & $0.100 \quad 0.005$ & & & & & & & \\
\hline $\begin{array}{l}\text { Mental health } \\
\text { limitations }\end{array}$ & $-0.210 \quad 0.016$ & & & & & & & \\
\hline $\begin{array}{l}\text { Physical h- } \\
\text { ealth limit- } \\
\text { ations }\end{array}$ & $0.240 \quad 0.002$ & & & & & & & \\
\hline Age & & & & & & & -0.020 & 0.000 \\
\hline Education & $0.090 \quad 0.041$ & & & & & & & \\
\hline Sex & & & $0.300 \quad 0.002$ & & & & 0.310 & 0.004 \\
\hline$F(\mathrm{df})$ & $35.2(10,313)$ & $60.1(6,325)$ & $70.6(5,392)$ & $29.7(7,295)$ & $41.8(5,348)$ & $19.9(6,342)$ & 27.6 & $(5,373)$ \\
\hline$R^{2}$ & 0.53 & 0.53 & 0.47 & 0.41 & 0.38 & 0.26 & & 27 \\
\hline
\end{tabular}

$\dagger$ Nonsignificant results are not displayed

pairs of variables cannot be directly inferred from the analysis. For example, although it is hypothesized here that perceived waterway condition is a predictor of place attachment, the reverse could also be true (Bonaiuto et al. 1996), as people with stronger levels of place attachment could perceive environmental condition to be better than it was.

\section{Comparison between regions}

In both regions, there were two significant pathways that linked recreational visits to waterways with quality of life. Physical place attachment increased with increasing frequency of waterway visits; this was related to place belonging, which was a significant determinant of quality of life. Increased visits also led to increased casual social interaction, which was positively related to network size, and this to quality of life. As recreational visits were linked with at least one aspect of perceived waterway condition in most waterways, this offers support for the hypothesis that coastal waterway condition may measurably affect human wellbeing. The fact that these paths were found in both study areas, despite considerable differences between the communities, offers strong support for the conclusions drawn here. However, there were some differences between the study areas that are worth exploring. This is perhaps not entirely unexpected; it is logical to suppose that some mechanisms linking environmental condition to human well-being may be stronger or weaker in some regions than others.

In the Douglas region, sense of place was more closely related to trust and reciprocity than was the case in the Pumicestone region, and community involvement was positively related to health and quality of life, independent of social networks. In the Pumicestone region, community involvement 
did not lead to wider social networks. Sense of place and social capital measures were all higher in the Douglas area than in Pumicestone. The reason for the differences between the two regions is not immediately obvious from the survey results. The Douglas region has a smaller and less densely settled population, which is distributed in several small communities throughout the region; each of these is physically separated from other communities and has its own individual character. In contrast, in the Pumicestone region, many people live in generic, contiguous suburbs that do not have clear boundaries. In addition, many people commute to Brisbane for work and other activities, further weakening local ties. One definition of community includes the concept of locality; a place in which people meet their daily needs together (Eisenhauer et al. 2000). People in the Pumicestone region are more likely to "meet their daily needs" outside the catchment area. They are also more likely to interact regularly with people outside the region, so their feelings of trust, and their social networks may less likely be related to local people and places. This is partially supported by the fact that trust was related to social networks of friends and relatives in the Pumicestone region, but to casual social interaction in the Douglas region; reciprocity was also related to casual social interaction in Douglas but not in Pumicestone. Another possible reason for the difference is that the average length of residence of respondents was longer for the Douglas than the Pumicestone region. Length of residence was significantly related to some aspects of sense of place in both study areas. Further research on the effect of length of residence, population size, density, and geographical spread on sense of place, social capital, and quality of life would be of interest.

\section{Implications for coastal management}

Although the relationship between the condition of the coastal environment and the number of coastal recreational visits was weak, the path analysis results showed that recreation in coastal areas had definite benefits for overall well-being. As most people preferred to visit waterways nearby, there is a case for ensuring that the condition of all waterways is maintained or improved, to improve the well-being of local residents. Other authors have also found that people generally prefer to visit natural areas close to them, and may not substitute other areas, even if they have similar uses (Kaltenborn 1998, Eisenhauer et al. 2000). It has been suggested that waterways in poor condition could be "sacrificed" and left in a poor condition when the cost of rehabilitation is perceived to be expensive (Spurgeon 1998). This study suggests that this strategy would be detrimental to the wellbeing of people living in the vicinity of the waterway, because they would not necessarily compensate by using an alternative waterway further away. Regional environmental condition also needs to be considered in this case; if all waterways within reasonable travel distance were in poor condition, there would be no options for regular coastal recreation.

This research adds to the growing body of literature that suggests that maintaining natural areas in a good condition is a necessary part of human well-being. It has been suggested that the increase in lifestyle and stress-related diseases in western societies may in part be due to a lack of contact with natural areas and growing dissociation between people and place (Maller et al. 2002). This study, although not designed to offer a controlled test of this hypothesis, does provide some observational support for this theory, and offers a starting point for further research. An important next step would be to determine how people choose a given waterway to visit, or whether to visit at all, motivations for visiting, and how the features of a particular waterway affect the activities that are undertaken and the development of place attachment.

Coastal managers are accountable for the impacts of management decisions on the coastal population. A better understanding of the positive impacts that may arise as a result of improvements, or the damage that could result from deterioration of waterway condition, is necessary to ensure that decisions are beneficial for both the environment and the resident human population.

\section{CONCLUSION}

This study investigates links between human wellbeing and the condition of natural environments, and provides evidence that the quality of the natural environment can have implications for social wellbeing and human quality of life. As such, it offers strong support for continued efforts to improve the condition of natural environments. These efforts should be applied to all areas, including ones currently in poor condition, because people are most affected by the condition of systems close to them. 
Further analysis of the relationship between environmental condition and quality of life in different locations and different ecosystems would contribute much to the discussion. Ideally, managers should be able to use assessments like this to quantify the impacts of management actions or potential developments on the well-being and quality of life of the human population associated with the ecosystem.

Responses to this article can be read online at:

http://www.ecologyandsociety.org/voll1/iss 1/art35/responses/

\section{Acknowledgments:}

The authors would like to thank Catherine de Voil, Susie Green, Darcelle Hegarty, John Scotese, and Vanessa Walker for assistance in delivering the survey; Brad Jorgensen for survey advice; Brendan Farthing for statistical advice; Rob Fearon, Regina Souter and anonymous reviewers for helpful comments; and staff from Caboolture, Caloundra and Douglas Councils for GIS data. We would also like to sincerely thank all those who gave up their time to participate in the survey. Funding for this research was provided by the Cooperative Research Centre for Coastal Zone, Estuary and Waterway Management and the Queensland Government Smart State Program.

\section{LITERATURE CITED}

Achat, H., I. Kawachi, S. Levine, C. Berkey, E. Coakley, and G. Colditz. 1998. Social networks, stress, and health-related quality of life. Quality of Life Research 7(8):735-750.

Australian Bureau of Statistics. 2002. Census basics 2001. Australian Bureau of Statistics, Canberra, Australia.

Berkman, L. F., and S. L. Syme. 1979. Social networks, host resistance, and mortality: a nine-year follow-up study of Alameda County residents. American Journal of Epidemiology 109(2):186-204.

Bonaiuto, M., G. Breakwell, and I. Cano. 1996. Identity processes and environmental threat: the effects of nationalism and local identity upon perception of beach pollution. Journal of Community and Applied Social Psychology 6:157-175.

Bonaiuto, M., A. Aiello, M. Perugini, M. Bonnes, and A. P. Ercolani. 1999. Multidimensional perception of residential environment quality and neighbourhood attachment in the urban environment. Journal of Environmental Psychology 19 (4):331-352.

Brown, G. G., P. Reed, and C. C. Harris. 2002. Testing a place-based theory for environmental evaluation: an Alaska case study. Applied Geography 22(1):49-76.

Carrus, G., M. Bonaiuto, and M. Bonnes. 2005. Environmental concern, regional identity, and support for protected areas in Italy. Environment and Behavior 37(2):237-257.

Chipuer, H. M., and G. M. H. Pretty. 1999. A review of the sense of community index: current uses, factor structure, reliability, and further development. Journal of Community Psychology 27 (6):643-658.

Chipuer, H. M., P. Bramston, and G. M.H.Pretty. 2003. Determinants of subjective quality of life among rural adolescents: a developmental perspective. Social Indicators Research 61 (1):79-95.

Cohen, S., W. J. Doyle, D. P. Skoner, B. S. Rabin, and J. M. Gwaltney. 1997. Social ties and susceptibility to the common cold. Jama-Journal of the American Medical Association 277(24):1940-1944.

Cramer, V., S. Torgersen, and E. Kringlen. 2004. Quality of life in a city: the effect of population density. Social Indicators Research 69(1):103-116.

Department of Local Government and Planning (DLGP). 2002. Queensland population update. Planning Information and Forecasting Unit, DLGP, Brisbane, Australia.

Dillman,D.A. 1991. The design and administration of mail surveys. Annual Review of Sociology 17:225-249.

Driver, B. L., P. J. Brown, and G. L. Peterson. 1991. Benefits of leisure. Venture Publishing, State College, Pennsylvania, USA. 
Eisenhauer, B. W., R. S. Krannich, and D. J. Blahna. 2000. Attachments to special places on public lands: an analysis of activities, reason for attachments, and community connections. Society and Natural Resources 13(5):421-441.

ESRI. 1999. Arcmap 8.1. Redlands, California, USA.

Idler, E. L., and Y. Benyamini. 1997. Self-rated health and mortality: a review of twenty-seven community studies. Journal of Health and Social Behaviour 38:21-37.

Insightful. 2001. S-plus version 6. Insightful, Seattle, Washington, USA.

Jöreskog, K., and D. Sörbom. 2001. Lisrel. Scientific Software International, Lincolnwood, Illinois, USA.

Jorgensen, B. S., and R. C. Stedman. 2001. Sense of place as an attitude: lakeshore owners' attitudes toward their properties. Journal of Environmental Psychology 21(3):233-248.

Kaltenborn, B. P. 1998. Effects of sense of place on responses to environmental impacts-a study among residents in Svalbard in the Norwegian High Arctic. Applied Geography 18(2):169-189.

Kawachi, I. 1999. Social capital and community effects on population and individual health. Pages 120-130 in N. E. Adler, editor. Socioeconomic status and health in industrial nations. New York Academy of Sciences, New York, New York, USA.

Kennedy, B. P., and I. Kawachi. 1998. The role of social capital in the Russian mortality crisis. World Development 26(11):2029-2043.

Kline, R. B. 1998. Principles and practice of structural equation modeling. Guildford, New York, New York, USA.

Kuo, F. E., W. C. Sullivan, R. L. Coley, and L. Brunson. 1998. Fertile ground for community: inner-city neighborhood common spaces. American Journal of Community Psychology 26(6):823-851.

Kweon, B. S., W. C. Sullivan, and A. R. Wiley. 1998. Green common spaces and the social integration of inner-city older adults. Environment and Behavior 30(6):832-858.
Lochner, K., I. Kawachi, and B. P. Kennedy. 1999. Social capital: a guide to its measurement. Health and Place 5(4):259-270.

MacDougall, C., R. Cooke, N. Owen, K. Willson, and A. Bauman. 1997. Relating physical activity to health status, social connections, and community facilities. Australian and New Zealand Journal of Public Health 21(6):631-637.

Maller, C., M. Townsend, P. Brown, and L. S. Leger. 2002. Healthy parks healthy people: the health benefits of contact with nature in a park context. Parks Victoria, Melbourne, Australia.

Michalos, A. C. 2004. Social indicators research and health-related quality of life research. Social Indicators Research 65(1):27-72.

Neff, L. J., B. E. Ainsworth, F. C. Wheeler, S. E. Krumwiede, and A. J. Trepal. 2000. Assessment of trail use in a community park. Family and Community Health 23(3):76-84.

Onyx, J., and P. Bullen. 2000. Measuring social capital in five communities. The Journal of Applied Behavioural Science 36(1):23-42.

Pendleton, L., N. Martin, and D. G. Webster. 2001. Public perceptions of environmental quality: a survey study of beach use and perceptions in Los Angeles County. Marine Pollution Bulletin 42 (11):1155-1160.

Pretty, G. H., H. M. Chipuer, and P. Bramston. 2003. Sense of place amongst adolescents and adults in two rural Australian towns: the discriminating features of place attachment, sense of community, and place dependence in relation to place identity. Journal of Environmental Psychology 23 (3):273-287.

Romans, S. E., V. A. Walton, G. P. Herbison, and P. E. Mullen. 1992. Social networks and psychiatric morbidity in New-Zealand women. Australian and New Zealand Journal of Psychiatry 26(3):485-492.

Rosenfeld, R., S. F. Messner, and E. P. Baumer. 2001. Social capital and homicide. Social Forces 80 (1):283-310.

Smith, D. G., G. F. Croker, and K. McFarlane. 1995. Human perception of water appearance. 1. Clarity and colour for bathing and aesthetics. New 
Zealand Journal of Marine and Freshwater Research 29(1):29-43.

Sobels, J., A. Curtis, and S. Lockie. 2001. The role of landcare group networks in rural Australia: exploring the contribution of social capital. Journal of Rural Studies 17(3):265-276.

Spurgeon, J. 1998. The socio-economic costs and benefits of coastal habitat rehabilitation and creation. Marine Pollution Bulletin 37(8-12):373-382.

Stedman, R. C. 2003. Is it really just a social construction? The contribution of the physical environment to sense of place. Society and Natural Resources 16(8):671-685.

Svendsen, G. L. H., and G. T. Svendsen. 2000. Measuring social capital: the Danish co-operative dairy movement. Sociologia Ruralis 40(1):72-86.

Tay, J. B., C. C. Kelleher, A. Hope, M. Barry, S. N. Gabhainn, and J. Sixsmith. 2004. Influence of sociodemographic and neighbourhood factors on self rated health and quality of life in rural communities: findings from the agriproject in the republic of Ireland. Journal of Epidemiology and Community Health 58(11):904-911.

Uchino, B. N., D. Uno, and J. Holt-Lunstad. 1999. Social support, physiological processes, and health. Current Directions in Psychological Science 8 (5):145-148.

Vlek, C., M. Skolnik, and B. Gatersleben. 1998. Sustainable development and quality of life: expected effects of prospective changes in economic and environmental conditions. Zeitschrift Fur Experimentelle Psychologie 45(4):319-333.

Williams, D. R., M. E. Patterson, J. W. Roggenbuck, and A. E. Watson. 1992. Beyond the commodity metaphor-examining emotional and symbolic attachment to place. Leisure Sciences $\mathbf{1 4}$ (1):29-46.

World Health Organization (WHO). 1999. Annotated bibliography. World Health Organization, Geneva, Switzerland. 


\section{Appendix 1. Measurement model diagrams}

\section{Please click here to download file 'appendix1.pdf'.}

